\title{
PsychologicAl TYPE AND THE PULPIT: AN EMPIRICAL ENQUIRY CONCERNING PREACHERS AND THE SIFT METHOD OF BIBLICAL HERMENEUTICS
}

\author{
Authors: \\ Leslie J. Francis \\ Amanda Robbins \\ Andrew Village 2
}

\section{Affiliations}

${ }^{1}$ Warwick Religions and Educations Research Unit, University of Warwick, United Kingdom

${ }^{2}$ Theology Department, York St John University, United Kingdom

\section{Correspondence to: Leslie J. Francis}

e-mail:

leslie.francis@warwick. ac.uk

\section{Postal address:}

Warwick Religions and

Education Research Unit, Institute of Education, University of Warwick, Coventry, CV4 7AL, United Kingdom

\section{Keywords:} psychological type; SIFT method; biblical hermenutics; Gospel of Mark; preachers

\section{Dates:}

Received: 05 Jan. 2009

Accepted: 26 Mar. 2009

Published: 03 Aug. 2009

How to cite this article: Francis, L.J., Robbins, A. \& Village, A., 2009, 'Psychological type and the pulpit: An empirical enquiry concerning preachers and the SIFT method of biblical hermeneutics', HTS Teologiese Studies/ Theological Studies 65(1), Art. \#161, 7 pages. DOI: 10.4102/hts.v65i1.161

\section{This article is available} at: http://www.hts.org.za

(C) 2009. The Authors. Licensee: OpenJournals Publishing. This work is licensed under the Creative Commons Attribution License.

\section{ABSTRACT}

A sample of 389 experienced preachers completed a measure of psychological type. They then read Mark 1:29-39 and recorded their evaluations of the four reflections on this passage proposed by Francis (1997) and which were derived from the SIFT method of biblical hermeneutics and liturgical preaching. Three main conclusions are drawn from these data. First, compared with the United Kingdom population norms, preachers within this sample were significantly more likely to prefer introversion, intuition, feeling and judging. Second, preachers were four times more likely to prefer a sensing interpretation of the text rather than a thinking interpretation, emphasising the richness of the narrative rather than facing the theological questions posed by it. Third, there was little evidence to suggest that preachers were less likely to appreciate interpretations consonant with their less preferred or inferior function than those consonant with their most preferred or dominant function. In this sense, the richness of the SIFT method should be accessible to preachers of all psychological types.

\section{INTRODUCTION}

Psychological type theory proposes a model of the human mind and of mental functioning that has proved itself to be accessible and attractive to several branches of practical theology (Baab 1998; Duncan 1993; Goldsmith \& Wharton 1993; Michael \& Norrisey 1984; Osborn \& Osborn 1991), even though the application of this theory remains controversial among some religious and theological commentators (Leech 1996; Lloyd 2007). Psychological type theory has its origins in pioneering and creative work by Carl Jung (see e.g., Jung 1971), but has been developed, clarified and popularised through a range of psychological assessment devices that have been applied within religious and theological contexts, most notably the Myers-Briggs Type Indicator (Myers \& McCaulley 1985), the Keirsey Temperament Sorter (Keirsey \& Bates 1978), and the Francis Psychological Type Scales (Francis 2005)

As generally understood, there are four key components to psychological type theory, and each of these four components can be experienced and expressed in two distinctive and opposing ways. The theory distinguishes between two orientations (introversion and extraversion), two perceiving processes (sensing and intuition), two judging processes (thinking and feeling), and two attitudes toward the outer world (judging and perceiving). The theory is attractive to practical theologians for two reasons. First, the level of human difference accessed by the theory is deep-seated and analogous to those differences associated with sex or with ethnicity. In this sense, psychological type differences may be associated with those differences intended by the divine creator and reflected in the diversity embraced by the divine image that encompasses both male and female (Gn 1:27). Second, the level of human difference accessed by the theory is well distinguished from other broader psychological constructs like personality (that embraces psychological abnormality as well as psychological normality) and character (that embraces moral evaluation). In this sense, psychological type differences are wholly benign and wholly value free. For example, to be characterised as introvert or as extravert carries connotations of neither pathology nor turpitude.

The two orientations are concerned with where psychological energy is drawn from and focused. On the one hand, extraverts are orientated toward the outer world: they are energised by the events and people around them. They enjoy communicating and thrive in stimulating and exciting environments. They tend to focus their attention on what is happening outside themselves. They are usually open people, easy to get to know, and enjoy having many friends. On the other hand, introverts are orientated toward their inner world: they are energised by their inner ideas and concepts. They enjoy solitude, silence, and contemplation, as they tend to focus their attention on what is happening in their inner life. They may prefer to have a small circle of intimate friends rather than many acquaintances.

The two perceiving functions are concerned with the way in which people perceive information. On the one hand, sensing types focus on the realities of a situation as perceived by the senses. They tend to focus on specific details, rather than on the overall picture. They are concerned with the actual, the real, and the practical, and they tend to be down to earth and matter of fact. On the other hand, intuitive types focus on the possibilities of a situation, perceiving meanings and relationships. They may feel that perception by the senses is not as valuable as information gained when indirect associations and concepts impact on their perception. They focus on the overall picture, rather than on specific facts and data.

The two judging functions are concerned with the processes by which people make decisions and judgements. On the one hand, thinking types make judgements based on objective, impersonal logic. They value integrity and justice. They are known for their truthfulness and for their desire for fairness. They consider conforming to principles to be of more importance than cultivating harmony. On the other hand, feeling types make judgements based on subjective, personal values. They value compassion and mercy. They are known for their tactfulness, for their desire for peace, and for their empathic capacity. 
They are more concerned to promote harmony than to adhere to abstract principles. The two attitudes toward the outer world are concerned with which of the two sets of functions (i.e. perceiving or judging) is preferred in dealings with the outer world. On the one hand, judging types seek to order, rationalise, and structure their outer world, as they actively judge external stimuli. They enjoy routine and established patterns. They prefer to follow schedules in order to reach an established goal and may make use of lists, timetables, or diaries. They tend to be punctual, organised and tidy. They prefer to make decisions quickly and to stick to their conclusions once made. On the other hand, perceiving types do not seek to impose order on the outer world, but are more reflective, perceptive, and open, as they passively perceive external stimuli. They have a flexible, open-ended approach to life. They enjoy change and spontaneity. They prefer to leave projects open in order to adapt and improve them. Their behaviour may often seem impulsive and unplanned.

Jung's view is that each individual develops one of the perceiving functions (sensing or intuition) at the expense of the other, and one of the judging functions (feeling or thinking) at the expense of the other. Moreover, for each individual, either the preferred perceiving function or the preferred judging function takes preference over the other, leading to the emergence of one dominant function which shapes the individual's dominant approach to life. Dominant sensing shapes the practical person. Dominant intuition shapes the imaginative person. Dominant feeling shapes the humane person. Dominant thinking shapes the analytic person. According to Jungian type theory, the function paired with the dominant function is known as the 'inferior function'. It is here that individuals experience most difficulty. Thus dominant sensers may struggle with intuition; dominant intuitives may struggle with sensing; dominant feelers may struggle with thinking; and dominant thinkers may struggle with feeling.

Within the broader field of the connection between psychological type theory and practical theology, there are two research traditions of particular relevance for exploring the relevance of psychological type theory for the pulpit. One of these research traditions has been largely empirically driven and concerns the psychological type characteristics of those who occupy the pulpit. The second of these research traditions has been largely theoretically driven and concerns the roles in the hermeneutical process of the perceiving functions of sensing and intuition (perception) and of the judging functions of thinking as feeling (evaluation).

\section{PSYCHOLOGICAL CHARACTERISTICS OF RELIGIOUS PROFESSIONALS}

Studies reported from the late 1960s within the United States of America began to establish a picture of the psychological type profile of religious professionals from across a range of backgrounds, including Jewish clergymen (Greenfield 1969), seminarians (Harbaugh 1984; Holsworth 1984), Catholic sisters (Bigelow et al., 1988; Cabral 1984), and both Protestant and Catholic clergy (Macdaid, McCaulley \& Kainz 1986). More recently, a series of studies has profiled religious professionals working in the United Kingdom, covering a range of different theological traditions, a range of different denominations, and a range of different church orientations. These studies include Presbyterian Church of Scotland ministers (Irvine 1989), male and female Bible College students (Francis, Penson \& Jones 2001), evangelical church leaders (Francis \& Robbins 2002; Craig, Francis \& Robbins 2004), male missionary personnel (Craig, Horsfall \& Francis 2005), evangelical lay church leaders (Francis, Craig, Horsfall \& Ross 2005), Roman Catholic priests (Craig, Duncan \& Francis 2006), youth ministers (Francis, Nash, Nash \& Craig 2007), evangelical Anglican seminarians (Francis, Craig \& Butler 2007), Assemblies of God theological college students (Kay \& Francis 2008; Kay, Francis \& Craig 2008), leaders within the Newfrontiers network of churches (Francis, Gubb \& Robbins in press; Ryland, Francis \& Robbins in press), and Anglican clergy (Francis, Craig, Whinney, Tilley \& Slater 2007a; Francis, Payne \& Jones 2001).

Two main conclusions emerge from the diverse data generated from these various studies. First, there are some consistent associations between psychological type profile and church background. For example, in terms of different denominations, there is a higher proportion of extraverts among leaders in the Newfrontiers network of churches than among Anglican clergy; in terms of different theological traditions, there is a higher proportion of intuitives within liberal traditions than within conservative traditions; in terms of different church orientations, there is a higher proportion of thinkers within evangelical churches than within Catholic churches. Second, in spite of these internal differences within religious professionals, there is overall a consistent pattern of differences between the psychological type profile of religious professionals and the psychological type profile of the population as a whole. This consistent pattern of differences is reflected in four ways.

First, religious professionals contain a higher proportion of introverts than are found in the population as a whole. This is consistent with the view that overall the Christian tradition tends to value the interior life and to promote an introverted path of spirituality.

Second, religious professionals contain a higher proportion of intuitives than are found in the population as a whole. This is consistent with the view that overall the Christian tradition encourages its followers to pursue a vision beyond the here-andnow, to challenge the conventional, and to set off in pursuit of the promised future.

Third, religious professionals contain a higher proportion of feelers than are found in the population as a whole. This is consistent with the view that overall the Christian tradition is concerned with inter-personal relationships, with personal values and standards, and with the major themes of peace and harmony.

Fourth, religious professionals contain a higher proportion of judgers than are found in the population as a whole. This is consistent with the view that, overall, the Christian tradition promotes an ordered and structured life style, reflected in disciplined practice, regular patterns and a predictable framework.

Finally, the differences between the psychological type profile of religious professionals and the population as a whole need to be interpreted against the general distribution of psychological type within the population. According to Kendall (1998), in terms of orientation, the United Kingdom population shows a slight preference for extraversion (52\%) over introversion (48\%); in terms of perceiving, the United Kingdom population shows a marked preference for sensing $(77 \%)$ over intuition $(24 \%)$; in terms of judging, the United Kingdom population shows a preference for feeling (54\%) over thinking $(46 \%)$; in terms of attitude toward the outer world, the United Kingdom population shows a preference for judging (58\%) over perceiving (42\%).

\section{PSYCHOLOGICAL TYPE AND HERMENEUTICS}

Serious reflection on the implications of psychological type theory for hermeneutics, for biblical interpretation and for preaching, was tested in an initial examination of passages from Mark's Gospel by Francis (1997) in a book entitled Personality type and scripture: Exploring Mark's Gospel. In three subsequent publications, Francis and Atkins (2000, 2001, 2002) applied the developing SIFT method of biblical hermeneutics to the principal Sunday gospel readings identified by the three year Revised Common Lectionary. The theoretical principles underpinning the SIFT method have been subsequently developed, tested and 
refined in a series of papers by Francis $(2003,2006 a, 2006 b, 2007)$, and consolidated by Francis and Village (2008) in their book entitled Preaching with all our souls. ${ }^{1}$

In essence, the SIFT method of biblical hermeneutics and liturgical preaching systematically addresses to each passage of scripture the four sets of questions posed by the four psychological functions of sensing (S), intuition (I), feeling (F), and thinking (T). The two perceiving functions (sensing and intuition) are applied first, since the perceiving process is concerned with gathering information and ideas. This is what Jung referred to as the irrational process, because it is unconcerned with making judgements or with formulating evaluations. The two judging functions (feeling and thinking) are applied second, since the judging process is concerned with evaluating information and ideas. Both feeling and thinking are described by Jung as rational functions, since they are concerned with making judgements and with formulating evaluations.

The first step in the SIFT method is to address the sensing perspective. It is the sensing perspective which gets to grip with the text itself, and which gives proper attention to the details of the passage, and may wish to draw on insights of historical methods of biblical scholarship in order to draw in 'facts' from other parts of the Bible. The first set of questions asks: 'How does this passage speak to the sensing function? What are the facts and details? What is there to see, to hear, to touch, to smell, and to taste?'

When sensing types hear a passage of scripture they want to savour all the detail of the text and may become fascinated by descriptions that appeal to their senses. They tend to start from a fairly literal interest in what is being said. Sensing types may want to find out all they can about the passage and about the facts that stand behind the passage. They welcome preachers who lead them into the passage by repeating the story and by giving them time to observe and to appreciate the details. Sensing types quickly lose the thread if they are bombarded with too many possibilities too quickly.

The second step in the SIFT method is to address the intuitive perspective. It is the intuitive perspective which relates the biblical text to wider issues and concerns. The second set of questions asks: 'How does this passage speak to the intuitive function? What is there to speak to the imagination, to forge links with current situations, to illuminate issues in our lives?'

When intuitive types hear a passage of scripture they want to know how that passage will fire their imagination and stimulate their ideas. They tend to focus not on the literal meaning of what is being said, but on the possibilities and challenges implied. Intuitive types may want to explore all of the possible directions in which the passage could lead. They welcome preachers who throw out suggestions and brainstorm possibilities, whether or not these are obviously linked to the passage, whether or not these ideas are followed through. Intuitive types quickly become bored with too much detail, too many facts and too much repetition.

The third step in the SIFT method is to address the feeling perspective. It is the feeling perspective which examines the human interest in the biblical text and learns the lessons of God for harmonious and compassionate living. The third set of questions asks: 'How does this passage speak to the feeling function? What is there to speak about fundamental human values, about the relationships between people, and about what it is to be truly human?'

When feeling types hear a passage of scripture they want to

1.In defining the SIFT method, the following convention has been used: sensing (S), intuition (I), feeling (F) and thinking $(T)$. It needs to be recognised that this is at variance with the broader convention within the psychological type literature where the following convention is used: introversion (I) and intuition (N). know what the passage has to say about personal values and about human relationships. They empathise deeply with people in the story and with the human drama in the narrative. Feeling types are keen to get inside the lives of people about whom they hear in scripture. They want to explore what it felt like to be there at the time and how those feelings help to illuminate their Christian journey today. They welcome preachers who take time to develop the human dimension of the passage and who apply the passage to issues of compassion, harmony, and trust. Feeling types quickly lose interest in theological debates which explore abstract issues without clear application to personal relationships.

The fourth step in the SIFT method is to address the thinking perspective. It is the thinking perspective which examines the theological interest in the biblical text and which reflects rationally and critically on issues of principle. The fourth set of questions asks: 'How does this passage speak to the thinking function? What is there to speak to the mind, to challenge us on issues of truth and justice, and to provoke profound theological thinking?'

When thinking types hear a passage of scripture they want to know what the passage has to say about principles of truth and justice. They get caught up with the principles involved in the story and with the various kinds of truth claims being made. Thinking types are often keen to do theology and to follow through the implications and the logic of the positions they adopt. Some thinkers apply this perspective to a literal interpretation of scripture, while other thinkers are more at home with the liberal interpretation of scripture. They welcome preachers who are fully alert to the logical and to the theological implications of their themes. They value sermons which debate fundamental issues of integrity and righteousness. Thinking types quickly lose interest in sermons which concentrate on applications to personal relationships, but fail to debate critically issues of theology and morality.

Although the research method leading to the development of the SIFT method of biblical hermeneutics and liturgical preaching has been largely theoretically driven, there are a couple of empirical studies that have examined this theoretical development. In the first study, Bassett, Mathewson and Gailitis (1993) examined the link between preferred interpretations of scripture and psychological preferences established partly by psychological type theory and partly by a measure of problem solving styles. Participants were asked to read four passages from New Testament epistles and then offered a choice of interpretations that were intended to express preferences for 'thinking' or for 'feeling' (as defined by psychological type theory) and preferences for 'collaborative', for 'deferring', or for 'independent' (as defined by their problem solving typology). Although mixing two personality models makes the results difficult to interpret, the data provided some support for a link between psychological type preference and choice of interpretations. Most obviously those classed as feeling types showed a preference for feeling-type interpretations.

In the second study, Village and Francis (2005) invited a sample of 404 lay adult Anglicans from 11 different churches to read a healing story from Mark's gospel and then to choose between pairs of interpretative statements designed to distinguish between the perceiving functions (sensing and intuition) or between the judging functions (thinking and feeling). The participants also completed the Keirsey Temperament Sorter (Keirsey \& Bates 1978) as a measure of psychological type. The data demonstrated that, when forced to choose between contrasting options, participants preferred interpretations that matched their psychological type preferences in both the perceiving process and the judging process.

\section{RESEARCH AGENDA}

Against the background established by the foregoing review, the 
objective of the present study is to build on previous research in four ways by designing and conducting a new study among experienced preachers (lay and ordained) attending continuing professional development sessions concerned with the theory and practice of preaching.

The first aim is to compare the psychological type profile of this group of preachers with the population norms provided for the United Kingdom by Kendall (1998). In the light of previous research, it is hypothesised that, compared with the population norms, a diverse group of experienced preachers will contain higher proportions of introverts, intuitives, feelers, and judgers.

The second aim is to examine the association between dominant type preferences and preferences for biblical interpretation. It is hypothesised that the order of preference will reflect the broader distribution of dominant type preferences within the wider Christian community in general and among preachers in particular. For example, according to Francis et al.(2001a), the distribution of dominant types among Anglican clergy are sensing $(35 \%)$, feeling $(30 \%)$, intuition $(23 \%)$ and thinking $(12 \%)$.

The third aim is to develop a measure of affective appreciation for biblical interpretations which can be used to assess and to compare responses to different biblical interpretations using a common metric. It is hypothesised that a small number of affective phrases will fulfil this function rated on a classic Likerttype five-point scale (Likert 1932).

The fourth aim is to employ the newly developed measure of affective appreciation for biblical interpretation to test the association between the preachers' personal psychological type profile and preferences for different interpretations. Specifically it is hypothesised that the sensing interpretation will be less preferred by intuitives, that the intuitive interpretation will be less preferred by sensers, that the feeling interpretation will be less preferred by thinkers, and that the thinking interpretation will be less preferred by feelers.

\section{Procedure}

\section{METHOD}

As part of an established continuing professional development programme for preachers, participants were invited to complete a recognised measure of psychological type and to complete the Personality and Preaching Survey. It was explained that the submission of this survey at the end of the course indicated permission for the data to be used for research purposes on the clear understanding that all responses were anonymised. Very few participants declined to participate in the research. All told data were provided by 389 preachers.

The Personality and Preaching Survey presented the gospel passage Mark 1:29-39, followed by the four interpretations offered by Francis (1997), intended to reflect the perspectives of sensing, intuition, feeling and thinking. These four interpretations were identified as A, B, C and D and not by the SIFT perspectives that they represented.

\section{Measures}

Psychological type was generally assessed by the 126-item Form G (Anglicised) of the Myers-Briggs Type Indicator (Myers \& McCaulley 1985). This instrument uses a forcechoice questionnaire format to indicate preferences between extraversion or introversion, sensing or intuition, thinking or feeling, and judging or perceiving. Broad support for the reliability and validity of the instrument is provided in the international literature, as summarised by Francis and Jones (1999) who additionally demonstrated the stability of the scale properties of the instrument among a sample of 429 adult churchgoers. In another study among 863 Anglican clergy,
Francis et al. (2007a) reported the following alpha coefficients: extraversion, .80; introversion, .79; sensing, .87; intuition, .82; thinking, .79; feeling, .72; judging, .85; perceiving, .86 .

Interpretative preference was assessed by the request, 'Now that you have read all four reflections, please rank the four reflections in the order of your preference'.

Affective appreciation for biblical interpretation was assessed by a series of nine phrases introduced by the question, 'How much does this interpretation ...', (seven positive and two negative) rated on a five-point scale where 1 was anchored by 'low' and 5 was anchored by 'high'. The nine phrases were: catch your attention; interest you; irritate you; inspire you; reflect your understanding of the gospel; touch issues that are important to you; make you switch off; deepen your faith; help you on your Christian journey.

\section{RESULTS AND DISCUSSION Research question one}

In the light of previous research among a wide range of lay and ordained church leaders, it was hypothesised that, compared with the population norms provided for the United Kingdom by Kendall (1998), the present diverse group of experienced preachers will contain higher proportions of introverts, intuitives, feelers and judgers. Table 1 presents the research data designed to address this specific research question in the form of a conventional type table. Type tables promote the detailed comparison of psychological type data across different studies and conventionally compare the type profile of different groups by means of the Selection Ratio Index (SRI), an extension of chi-squared contingency tables. These data confirmed all four hypotheses: $62 \%$ of preachers preferred introversion, compared with $48 \%$ of the United Kingdom population; $48 \%$ of preachers preferred intuition, compared with $24 \%$ of the United Kingdom population; $62 \%$ of preachers preferred feeling, compared with $54 \%$ of the United Kingdom population; and $74 \%$ of preachers preferred judging, compared with $58 \%$ of the United Kingdom population. $N$

These findings carry two kinds of implications for the ministry of preachers. First, preachers and church leaders in general may have a significant influence on (and opportunity to model) the kinds of worshipping communities over which they preside. Here are people who may be more adept at fostering introverted, intuitive, feeling and judging perspectives on worship than reflects the over disposition of the United Kingdom population as a whole. Such communities may appear less attractive to extrverted, sensing, thinking and perceiving potential members. Second, their personality characteristics may help to illuminate areas of ministry in which preachers and church leaders may excel and areas in which they may struggle. In particular, preference for introversion may indicate strengths in in-depth, one-onone encounters, but less facility with community leadership; preference for feeling may indicate a heightened pastoral awareness, but less facility with tough management; preference for judging may indicate strengths for structural organisation, but less facility with flexible and creative spontaneity.

\section{Research question two}

In the light of previous research, it was hypothesised that preferences for scriptural interpretation crafted within the SIFT method of biblical hermeneutics and liturgical preaching will reflect the broader distribution of dominant type preferences within the wider Christian community in general, and among preachers in particular. Specifically, the order of preference hypothesised was sensing, feeling, intuition and thinking, citing the type distribution reported by Francis et al. (2001a). The data presented in Table 1 demonstrated a similar but not identical order of dominant preferences: sensing (31\%), intuition $(29 \%)$, feeling $(25 \%)$, and thinking (15\%), at least confirming that sensing 
TABLE 1

Type Distribution for preachers, compared with the United Kingdom population norms

$N=389+=1 \%$ of $N \quad I=$ Selection Ratio Index $\quad{ }^{*}<.05{ }^{* *} \mathrm{p}<.01{ }^{* * *} \mathrm{p}<.001$

\begin{tabular}{|c|c|c|c|c|c|c|c|}
\hline \multicolumn{4}{|c|}{ The sixteen Complete Types } & \multicolumn{4}{|c|}{ Dichotomous Preference } \\
\hline ISTJ & ISFJ & INFJ & INTJ & $E$ & 147 & $(37.8 \%)$ & $* * * I=0.72$ \\
\hline$n=44$ & $n=69$ & $n=40$ & $n=34$ & 1 & 242 & $(62.2 \%)$ & $* * I=1.30$ \\
\hline (11.3\%) & $(17.7 \%)$ & (10.3\%) & $(8.7 \%)$ & & & & \\
\hline$I=0.83$ & $I=1.39^{* *}$ & $I-6.00^{* * *}$ & $I=6.21^{\star * *}$ & $S$ & 202 & $(51.9 \%)$ & $* * * I=0.68$ \\
\hline+++++ & +++++ & +++++ & +++++ & $\mathrm{N}$ & 187 & $(48.1 \%)$ & $* * * I=2.05$ \\
\hline+++++ & +++++ & +++++ & ++++ & & & & \\
\hline \multirow[t]{4}{*}{+} & +++++ & & & $\mathrm{T}$ & 148 & $(38.0 \%)$ & ${ }^{* *} I=0.83$ \\
\hline & +++ & & & $\mathrm{F}$ & 241 & $(62.0 \%)$ & $* * I=1.15$ \\
\hline & & & & $\mathrm{J}$ & 289 & $(74.3 \%)$ & ${ }^{* * *} I=1.28$ \\
\hline & & & & $\mathrm{P}$ & 100 & $(25.7 \%)$ & ${ }^{* * *} I=0.62$ \\
\hline
\end{tabular}

$\begin{array}{llll}\text { ISTP } & \text { ISFP } & \text { INFP } & \text { INTP } \\ n=2 & n=17 & n=26 & n=10 \\ (0.5 \%) & (4.4 \%) & (6.7 \%) & (2.6 \%) \\ I=0.08^{* * *} & I=0.71 & I=2.10^{* * *} & I=1.05 \\ + & ++++ & +++++ & +++ \\ & & ++ & \end{array}$

\section{Pairs and Temperaments}

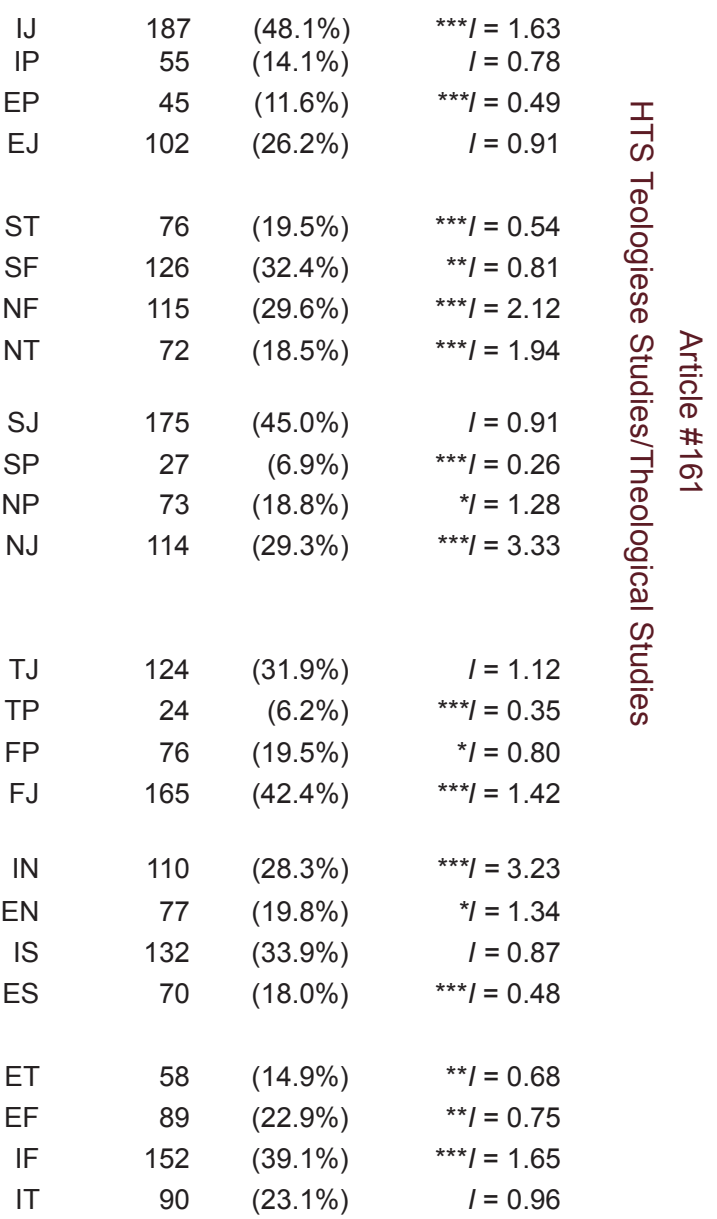

\begin{tabular}{|c|c|c|c|c|c|c|c|c|c|c|c|c|}
\hline \multicolumn{4}{|c|}{ Jungian Types (E) } & \multicolumn{5}{|c|}{ Jungian Types (I) } & \multicolumn{3}{|c|}{ Dominant Types } & \multirow[b]{2}{*}{ Francis, Village and Robbins } \\
\hline & $n$ & $\%$ & I & & $n$ & $\%$ & I & & $n$ & $\%$ & I & \\
\hline E-TJ & 46 & 11.8 & 0.89 & I-TP & 12 & 3.1 & $* * * 0.35$ & Dt.T & 58 & $14.9 \%$ & $* * * 0.67$ & \\
\hline $\mathrm{E}-\mathrm{FJ}$ & 56 & 14.4 & 0.94 & I-FP & 43 & 11.1 & 1.19 & Dt.F & 99 & $25.4 \%$ & 1.03 & Psychological types of preachers \\
\hline ES-P & 8 & 2.1 & ${ }^{* * *} 0.14$ & IS-J & 113 & 29.0 & 1.10 & Dt.S & 121 & $31.1 \%$ & $* * * 0.76$ & compared with the United \\
\hline EN-P & 37 & 9.5 & 1.05 & IN-J & 15 & 19.0 & $* * \star 6.09$ & Dt.N & 111 & $28.5 \%$ & $* * * 2.34$ & Kingdom population norms \\
\hline
\end{tabular}


TABLE 2

Measure of affective appreciation for biblical interpretation: Item rest-of-test correlations

\begin{tabular}{lcccc}
\hline & $\mathrm{S}$ & $\mathrm{N}$ & $\mathrm{F}$ & $\mathrm{T}$ \\
& $r$ & $r$ & $r$ & $r$ \\
\hline How much does this interpretation: & & & & \\
catch your attention & .71 & .71 & .76 & .71 \\
interest you & .82 & .82 & .84 & .82 \\
irritate you* & .71 & .68 & .63 & .60 \\
inspire you & .82 & .84 & .82 & .76 \\
reflect your understanding of the gospel & .76 & .75 & .76 & .77 \\
touch issues that are important to you & .79 & .72 & .79 & .68 \\
make you switch off* & .64 & .62 & .64 & .62 \\
deepen your faith & .80 & .78 & .81 & .77 \\
help you on your Christian journey & .82 & .82 & .85 & .79 \\
alpha & .94 & .93 & .94 & .92 \\
\hline
\end{tabular}

Note *these items are reverse coded.

is the most frequently occurring characteristic and thinking is the least frequently occurring characteristic.

When asked to rank order their preferences for the four example interpretations of Mark 1:29-39, 47\% of the preachers chose the sensing interpretation, $22 \%$ the feeling interpretation, $15 \%$ the intuitive interpretation, and $13 \%$ the thinking interpretation. If preachers' preferred interpretation indicates their own preaching style, these findings carry implications for the kinds of preaching that may be most frequently heard from the pulpits. On this account, nearly half of the sermons preached from pulpits may emphasise a sensing perspective on the text, compared with just one in eight that are likely to emphasise a thinking perspective on the text. Congregations are more likely to be exposed to the rich imagery and engaging narrative of scripture than to the tough theological issues and questions posed by scripture.

\section{Research question three}

The third aim was to develop a measure of affective appreciation for biblical interpretations which can be used to assess and to compare responses to different biblical interpretations using a common metric. It was hypothesised that a small number of affective phrases will fulfil this function rated on a classic Likert type five-point scale.

After reading the four interpretations of Mark 1:29-39 the preachers rated their affective appreciation on a five-point scale from 1 (low) to 5 (high) using the nine phrases presented in table 2. This table also presents for the four administrations (following the sensing, intuition, feeling and thinking interpretations), the correlations between the individual items, and the sum total of the other eight items, together with the alpha coefficient (Cronbach 1951). These data confirmed the high internal consistency reliability of the measure and commend the measure for further research application.

\section{Research question four}

The fourth aim was to employ the newly developed measure of affective appreciation for biblical interpretation to test the association between the preachers' personal psychological type profiles and preferences for different interpretations. Specifically it was hypothesised that the sensing interpretation will be less preferred by intuitives, that the intuitive interpretation will be less preferred by sensers, that the feeling interpretation will be less preferred by thinkers, and that the thinking interpretation will be less preferred by feelers. These hypotheses were advanced on the basis of Jung's theory that individuals have most difficulty in accessing their inferior function, that is the function opposite to their dominant preference.

The data partly confirm and partly contradict this set of hypotheses. On the one hand, two of the hypotheses were confirmed: the sensing interpretation was less well appreciated by intuitives $(r=-.14, p<.01)$; the feeling interpretation was less well appreciated by thinkers $(r=-.12, p<.01)$. On the other hand, two of the hypotheses were not confirmed: the intuitive interpretation was not less well appreciated by sensers $(r=-.04$ $\mathrm{ns})$; the thinking interpretation was not less well appreciated by feelers $(r=-.02$, ns). Moreover, even the statistically significant correlations accounted for only marginal proportions of variance.

These findings suggest that the four different perspectives of the SIFT method of biblical hermeneutics and liturgical preaching remain broadly accessible to preachers across the range of psychological types. Although dominant sensers may not naturally prefer to generate an intuitive style reflection on text, they are only mildly less appreciative of that perspective than intuitives themselves. Although dominant thinkers may not naturally prefer to generate a feeling style reflection on text, they are only mildly less appreciative of that perspective than feelers themselves. Although dominant intuitives may not naturally prefer to generate a sensing style reflection on text, they are no less appreciative of that perspective than sensers themselves. Although dominant feelers may not naturally prefer to generate a thinking style reflection on text, they are no less appreciative of that perspective than thinkers themselves.

\section{CONCLUSION}

The present study set out to explore from an empirical perspective the relevance of Jungian psychological type theory for preaching, for preachers, and for the pulpit. In so doing the study has built on and contributed to two fields of enquiry.

First, the study has added further information about the psychological type profile of preachers. The data have confirmed that, compared with the United Kingdom population as a whole, preachers are more likely to prefer introversion, intuition, feeling and thinking. It has been argued that these findings have implications for the ways in which churches are shaped, for the people to whom they minister, and for the ministry strengths and weaknesses of the preachers themselves.

Second, the study has added further information about the SIFT method of biblical hermeneutics and liturgical preaching. The data suggested two main points. The first point is that the preferred hermeneutical perspective reflects the psychological dominant preferences of the community of preachers themselves. A sensing perspective is four times more likely than a thinking perspective to be given priority. The second point is that, when presented with the full range of sensing, intuitive, feeling and thinking perspectives, these perspectives are appreciated almost equally by those for whom the perspective reflects the dominant preference and for those for whom it reflects the inferior preference. In this sense, the SIFT method of biblical hermeneutics and liturgical preaching should prove to be a viable and enabling method for all types of preachers.

There are three clear limitations of the present study which need to be addressed by future research. First, the present sample of preachers was ill defined and opportunistic in terms of those who participated in the continuing professional development programmes. Future research might be able to focus on defined cohorts of seminarians, serving ministers, or lay preachers. Second, the present sample selected just one example of the SIFT method at work, as displayed by Francis (1997) reflecting on Mark 1:29-39. Future research might be able to focus on multiple examples and so be less vulnerable to the idiosyncrasies of one set of reflections. Third, the present study set up a very simple research design that failed to take into account control variables or other potential predictors. Future research might be able to control for variables like sex, age and denomination, and to include additional predictor variables concerned with theological positions and interpretative stances.

Finally, the present study has examined the association between psychological type and appreciation of different interpretations 
of text. The research most needed next is a systematic evaluation of the texts generated by preachers who are naïve of the SIFT method in order to examine the extent to which the individual preacher's psychological type is indeed reflected in his or her preferred style of preaching.

\section{REFERENCES}

Baab, L.M., 1998, Personality type in congregations: How to work with others more effectively, Alban Institute, Washington, DC.

Bassett, R.L., Mathewson, K. \& Gailitis, A., 1993, 'Recognising the person in biblical interpretation: An empirical study', Journal of Psychology and Christianity 12, 38-46.

Bigelow, E.D., Fitzgerald, R., Busk, P., Girault, E. \& Avis, J., 1988, 'Psychological characteristics of Catholic sisters: Relationships between the MBTI and other measures', Journal of Psychological Type 14, 32-36.

Cabral, G., 1984, 'Psychological types in a Catholic convent: Applications to community living and congregational data', Journal of Psychological Type 8, 16-22.

Craig, C.L., Duncan, B. \& Francis, L.J., 2006, 'Psychological type preferences of Roman Catholic priests in the United Kingdom', Journal of Beliefs and Values 27, 157-164.

Craig, C.L., Francis, L.J. \& Robbins, M., 2004, 'Psychological type and sex differences among church leaders in the United Kingdom', Journal of Beliefs and Values 25, 3-13.

Craig, C.L., Horsfall, T. \& Francis, L.J., 2005, 'Psychological types of male missionary personnel training in England: A role for thinking type men?', Pastoral Psychology 53, 475-482.

Cronbach, L.J., 1951, 'Coefficient alpha and the internal structure of tests', Psychometrika 16, 297-334.

Duncan, B., 1993, Pray your way: Your personality and God, Darton, Longman \& Todd, London.

Francis, L.J., 1997, Personality type and scripture: Exploring Marks' gospel, Mowbray, London.

Francis, L.J., 2003, 'Psychological type and biblical hermeneutics: SIFT method of preaching', Rural Theology 1, 13-23.

Francis, L.J., 2005, Faith and psychology: Personality, religion and the individual, Darton, Longman \& Todd, London.

Francis, L.J., 2006a, 'Mark and psychological type', in J. Vincent, (ed.), Mark's Gospel of action: Personal and community responses, pp. 98-108, SPCK, London.

Francis, L.J., 2006b, 'Psychological type and liturgical preaching: The SIFT method', Liturgy 21(3), 11-20.

Francis, L.J., 2007, 'Psychological types', in F. Watts (ed.), Jesus and psychology, pp. 137-154, Darton, Longman \& Todd, London.

Francis, L.J. \& Atkins, P., 2000, Exploring Luke's Gospel: A guide to the gospel readings in the Revised Common Lectionary, Mowbray, London.

Francis, L.J., \& Atkins, P., 2001, Exploring Matthew's Gospel: A guide to the gospel readings in the Revised Common Lectionary, Mowbray, London.

Francis, L.J. \& Atkins, P., 2002, Exploring Mark's Gospel: An aid for readers and preachers using year $B$ of the Revised Common Lectionary, Continuum, London.

Francis, L.J., Craig, C.L. \& Butler, A., 2007, 'Psychological types of male evangelical Anglican seminarians in England', Journal of Psychological Type 67, 11-17.

Francis, L.J., Craig, C.L., Horsfall, T. \& Ross, C.F.J., 2005, 'Psychological types of male and female evangelical lay church leaders in England, compared with United Kingdom population norms', Fieldwork in Religion 1, 69-83.

Francis, L.J., Craig, C.L., Whinney, M., Tilley, D. \& Slater, P., 2007a, 'Psychological profiling of Anglican clergy in England: Employing Jungian typology to interpret diversity, strengths, and potential weaknesses in ministry', International Journal of Practical Theology 11, 266-284.

Francis, L.J., Gubb, S. \& Robbins, M., (in press), 'Psychological type profile of Lead Elders within the Newfrontiers network of churches in the United Kingdom'.

Francis, L.J. \& Jones, S.H., 1999, 'The scale properties of the MBTI Form G (Anglicised) among adult churchgoers', Pastoral Sciences 18, 107-126.
Francis, L.J., Nash, P., Nash, S. \& Craig, C.L., 2007, 'Psychology and youth ministry: Psychological type preferences of Christian youth workers in the United Kingdom', Journal of Youth Ministry 5(2), 73-90.

Francis, L.J., Payne, V.J. \& Jones, S.H., 2001, 'Psychological types of male Anglican clergy in Wales', Journal of Psychological Type 56, 19-23.

Francis, L.J., Penson, A.W. \& Jones, S.H., 2001a, 'Psychological types of male and female Bible College students in England', Mental Health, Religion and Culture 4, 23-32.

Francis, L.J. \& Robbins, M., 2002, 'Psychological types of male evangelical church leaders', Journal of Belief and Values 23, 217-220.

Francis, L.J. \& Village, A., 2008, Preaching with all our souls: A study in hermeneutics and psychological type, Continuum, London.

Goldsmith, M. \& Wharton, M., 1993, Knowing me knowing you, SPCK, London.

Greenfield, M., 1969, 'Typologies of persisting and non-persisting Jewish clergymen', Journal of Counselling Psychology 16, 368372.

Harbaugh, G.L., 1984, 'The person in ministry: Psychological type and the seminary', Journal of Psychological Type 8, 2332.

Holsworth, T.E., 1984, 'Type preferences among Roman Catholic seminarians', Journal of Psychological Type 8, 33-35.

Irvine, A.R., 1989, 'Isolation and the parish ministry', PhD dissertation, University of St Andrews.

Jung, C.G., 1971, Psychological types: The collected works, vol 6, Routledge \& Kegan Paul, London.

Kay, W.K. \& Francis, L.J., 2008, 'Psychological type preferences of female Bible College students in England', Journal of Beliefs and Values 29, 101-105.

Kay, W.K., Francis, L.J. \& Craig, C.L., 2008, 'Psychological type preferences of male British Assemblies of God Bible College students: Tough minded or tender hearted?', Journal of the European Pentecostal Theological Association 28, 6-20.

Keirsey, D. \& Bates, M., 1978, Please understand me, Prometheus Nemesis, Del Mar.

Kendall, E., 1998, Myers-Briggs Type Indicator: Step 1 manual supplement, Consulting Psychologists Press, Palo Alto.

Leech, K., (ed.), 1996, Myers-Briggs: Some critical reflections, The Jubilee Group, Croydon.

Likert, R., 1932, 'A technique for the measurement of attitudes', Archives of Psychology 140, 1-55.

Lloyd, J.B., 2007, 'Opposition from Christians to Myers-Briggs personality typing: An analysis and evaluation', Journal of Beliefs and Values 28, 111-123.

Macdaid, G.P., McCaulley, M.H. \& Kainz, R.I., 1986, Myers-Briggs type indicator: Atlas of type tables, Centre for Application of Psychological Type Inc, Gainesville.

Michael, C.P. \& Norrisey, M.C., 1984, Prayer and temperament: Different prayer forms for different personality types, The Open Door, Charlottesville.

Myers, I.B. \& McCaulley, M.H., 1985, Manual: A guide to the development and use of the Myers-Briggs Type Indicator, Consulting Psychologists Press, Palo Alto.

Osborn, L. \& Osborn, D., 1991, God's diverse people, Daybreak, London.

Ryland, A., Francis, L.J. \& Robbins, M., (in press), 'Called for leadership: Psychological type profile of leaders within the Newfrontiers network of churches in the United Kingdom'.

Village, A. \& Francis, L.J., 2005, 'The relationship of psychological type preferences to biblical interpretation', Journal of Empirical Theology 18, 74-89. 